Pesq. Vet. Bras. 38(4):767-772, abril 2018

\title{
Pelvimetry in Squirrel Monkeys (Saimiri scireus Linnaeus, 1758) ${ }^{1}$
}

\author{
Samantha M. Favoretto ${ }^{2 *}$, Elaine C. Landy ${ }^{3}$, Washington Luiz A. Pereira ${ }^{3}$, \\ Paulo Henrique G. Castro ${ }^{4}$, Aline A. Imbeloni ${ }^{4}$, José Augusto P.C. Muniz ${ }^{4}$, \\ Mariana A.S. Santos ${ }^{2}$ and Antonio C.C. Lacreta Junior ${ }^{2}$
}

\begin{abstract}
Favoretto S.M., Landy E.C., Pereira W.L.A., Castro P.H.G., Imbeloni A.A., Muniz J.A.P.C., Santos M.A.S. \& Lacreta Jr A.C.C. 2018. Pelvimetry in Squirrel Monkeys (Saimiri scireus Linnaeus, 1758). Pesquisa Veterinária Brasileira 38(4):767-772. Departamento de Medicina Veterinária, Universidade Federal de Lavras, Campus Universitário, Cx. Postal 3037, Lavras, MG 37200-000, Brazil. E-mail: samanthafavoretto@gmail.com

Saimiri sciureus is a neotropical primate widely used in research. However, there are still difficulties regarding their reproduction in vivaria due to the high incidence of dystocia. Dystocia in primates can be caused by cephalopelvic disproportion and in Squirrel Monkeys, pregnancy of large fetuses were reported. This paper describes pelvimetry data of adult females and subadults in specimens of Squirrel Monkeys, from a research colony of Para, Brazil. Pelvic radiographs were obtained in ventrodorsal projections and the following measurements were taken: superior bi-iliac diameter (SBID); inferior bi-iliac diameter (IBID); bi-iliac average diameter (BIAD); right diagonal diameter (RDD); left diagonal diameter (LDD); sacro-pubic diameter (SPD); Based on the obtained diameters, the entrance area of the pelvis (EAP) was also calculated. The average values of the pelvic diameters and EAP in adult females were SBID $1.714 \mathrm{~cm}$, BIAD $1.957 \mathrm{~cm}$, IBID $1.686 \mathrm{~cm}$, RDD $2.771 \mathrm{~cm}$, LDD $2.764 \mathrm{~cm}$, SPD $2.543 \mathrm{~cm}$ and EAP $3.9056 \mathrm{~cm}^{2}$; and subadult females: $1.588 \mathrm{~cm}$ SBID, $1.850 \mathrm{~cm}$ BIAD, $1.625 \mathrm{~cm}$ IBID, $2.50 \mathrm{~cm}$ RDD, LDD $2.474 \mathrm{~cm}, 1.95 \mathrm{~cm}$ SPD and $2.8293 \mathrm{~cm}^{2}$ EAP. Saimiri sciureus pelvis is characterized as dolichopelvic. There was statistical significance between the values for adult females and subadults to SBID, BIAD, RDD, LDD, SPD and EAP. The values of SBID and IBID were lower when compared to the published data for the same species. The result found on this paper will serve as a basis for future studies using pelvic measurements and dystocia prediction of neotropical primates and comparison between different vivaria.
\end{abstract}

INDEX TERMS: Pelvimetry, Squirrel Monkeys, Saimiri scireus, distocia, non-human primate, radiography, measure, morphology.

RESUMO.- [Pelvimetria em macacos-de-cheiro (Saimiri scireus Linnaeus, 1758).] Saimiri sciureus é uma espécie de primata neotropical muito utilizada como animal de pesquisa. No entanto ainda há dificuldades em biotérios quanto a sua reprodução devido à alta ocorrência de distocia. A distocia em primatas pode ter origem devido à desproporção cefalopélvica, sendo que em macacos-de-cheiro é relatada a gestação

\footnotetext{
${ }^{1}$ Received on September 15, 2016.

Accepted for publication on January 11, 2017.

${ }^{2}$ Departamento de Medicina Veterinária, Universidade Federal de Lavras, Campus Universitário, Cx. Postal 3037, Lavras, MG 37200-00, Brazil. *Corresponding author: samanthafavoretto@gmail.com

${ }^{3}$ Instituto de Saúde e Produção Animal, Universidade Federal Rural da Amazônia, Av. Perimetral 2501, Belém, PA 66077-901, Brazil.

${ }^{4}$ Centro Nacional de Primatas, Instituto Evandro Chagas, BR-316 Km 7, Ananindeua, PA 67030-000, Brazil.
}

de fetos grandes. 0 presente trabalho descreve dados de pelvimetria em espécimes de macaco-de-cheiro, fêmeas adultas e subadultas provenientes de uma colônia de pesquisa do Pará, Brasil. Foram realizadas radiografias da pelve em projeção ventrodorsal e por meio destas mensurados os diâmetros biilíaco superior (DBIS); diâmetro biíliaco inferior (DBII); diâmetro biilíaco médio (DBIM); diâmetro diagonal direito (DDD); diâmetro diagonal esquerdo (DDE); diâmetro sacro-púbico (DSP); com base nos diâmetros obtidos também foi calculada a área de entrada da pelve (AEP). Os valores médios dos diâmetros pélvicos e da AEP em fêmeas adultas foram: DBIS $1,714 \mathrm{~cm}$, DBIM $1,957 \mathrm{~cm}$, DBII $1,686 \mathrm{~cm}$, DDD 2,771 cm, DDE 2,764cm, DSP 2,543cm e AEP 3,9056 $\mathrm{cm}^{2}$; e para fêmeas subadultas: $1,588 \mathrm{~cm}$ DBIS, $1,850 \mathrm{~cm}$ DBIM, $1,625 \mathrm{~cm}$ DBII, 2,50cm DDD, 2,474cm DDE, $1,95 \mathrm{~cm}$ DSP e $2,8293 \mathrm{~cm}^{2}$ AEP. Observou-se que a pelve de Saimiri sciureus 
é dolicopélvica. Houve diferença estatística significativa entre os valores para fêmeas adultas e subadultas para DBIS, DBIM, DDD, DDE, DSP e AEP. Em comparação com dados da literatura de pelvimetria para $S$. sciureus observaram-se menores valores de DBIS e DBII. 0 resultado deste trabalho servirá como base para futuros estudos utilizando-se mensurações pélvicas e predição de distocia em primatas neotropicais e referência para comparação entre $S$. sciureus de diferentes biotérios.

TERMOS DE INDEXAÇ̃̃O: Pelvimetria, macaco-de-cheiro, Saimiri scireus, primata, radiografia, morfologia.

\section{INTRODUCTION}

Saimiri scireus, the Squirrel Monkey, is a neotropical primate from the Amazon region (Boubli et al. 2008). Due to its physical characteristics, such as its small size, the lower risk of zoonotic disease transmission when compared to the Old World primates, and the fact it is an easy creature to handle, the species has become popular as an animal used for research purposes (Andrade et al. 2004). They are currently used in biomedical research studies on the pathophysiology of cardiovascular disease, in reproductive aspects studies and in vaccine trials, particularly in malaria research (Andrade et al. 2010). Furthermore, it is frequently found in zoos for species maintenance purposes. Squirrel Monkeys are gregarious animals that adapt well to captivity. In their rooms, the animals are maintained in groups, which may be formed by only a couple or up to 35 to 50 animals, but with each group containing a maximum of two males only (Tardif et al. 2006). Reproduction of squirrel monkeys is marked by strong seasonality of females. They reach sexual maturity at 2.5 to 3.5 years of age and the gestation lasts about 150 days (Brady 2000). Captive conception rate is reasonable, though some have reproductive problems. The high susceptibility to stress causes high abortion rate. Still, there is a high incidence of dystocia due to the generation of large fetuses, which causes loss of individuals due to stillbirth or neonatal mortality (Abee 1989). One frequent cause of dystocia in cattle is the disproportion between the pelvis of the mother and the fetus. One of the ways to diagnose the risk of dystocia is through the measurement of the maternal pelvis (pelvimetry) and its relation to the size of the fetus (Ramin et al. 1995, Oliveira \& Gheller 2009, Nogalski \& Mordas 2012). In humans, there have been also previously reported cases of discrepancies between the size of the fetus and the maternal pelvis, this being correlated to the evolutionary relationship between the larger size of the brain and the bipedal position (Trevathan 2015). Recently, however, the cephalopelvic disparity has been correlated with dietary factors that lead to an increased size of the fetus (Wells et al. 2012). The pelvimetry technique provides information about the fetus-pelvis correlation is a low-cost and simple method and does not require chemical restraint in animals, except for wild animals and those with aggressive temperament (Cloete \& Haughey 1990, Van Donkersgoed et al. 1993). The pelvimetry is the study of the measurement of the pelvis by direct or indirect technique (Valle 2004), providing data which can be used especially in studies involving obstetrics and for selection of females for breeding programs (Campos 2010). Indirect pelvimetry through a radiographic study has been reported as a method of dystocia prediction in dogs (Eneroth et al. 1999). Studies performed on sheep found similarities when comparing values on the direct measurement through dissected pelvis and values obtained on $\mathrm{x}$-rays, concluding that the dimensions of the pelvis measured through radiographies can predict the actual size of the pelvis (Cloete \& Haughey 1990). There are already some reports in the literature regarding pelvimetry performances in primates in the new world. However, there is not enough data and its correlation with the occurrence of dystocia. Moreover there is not a standardization of primates from different colonies, so it is important to have data from different institutions that breed $S$. sciureus. This study describes the pelvic measurement of adult and subadults females of Squirrel Monkeys in a research colony in Belém, PA, Brazil and compares the data with published reports on this species and other primates.

\section{MATERIALS AND METHODS}

Animals. Eleven non-human female primates of the species Saimiri sciureus were used in this study. All the animals were clinically healthy and were kept in the breeding colony of the National Primate Center (CENP) of the Health Surveillance Secretariat of the Ministry of Health (CENP/SVS/MS) located in the district of Ananindeua, PA. The experiment was approved by the Ethics Commitee on Animal Use of Evandro Chagas Institute, Ananindeua, Para, Brazil.

Animals were divided into two groups according to their age: seven adult females, three years old minimum in group one; and four subadult females under three years old in group two.

Radiography. The animals were weighed and anesthetized (dissociative anesthesia) with an association of $10 \mathrm{mg} / \mathrm{kg}$ of ketamine hydrochloride, $0.2 \mathrm{mg} / \mathrm{kg}$ of midazolam and $0.2 \mathrm{mg} / \mathrm{kg}$ of methotrimeprazine, intramuscularly, according to the protocol recommended by Valle (2004).

In sequence, the animals were placed in a dorsal decubitus position with the hind limbs pulled caudally, so that the pelvis would be as parallel as possible to the examination table. For the radiographic imaging, we used Intecal ${ }^{\circledR}$ brand, CR-7 model with a capacity of 100 kilovolts $(\mathrm{kV})$ and 100 milliamps (mA). Radiographs were performed using standard technique for bone structures by using the thickness of the hip to calculate the Kv and the milliamperes per second ( $\mathrm{mAs}$ ) variables. The images were revealed on radiographic films size $24 \mathrm{~cm} \times 30 \mathrm{~cm}$, Kodak T-MAT G/RA brand and processed in manual revelation.

The measurements of the pelvis were performed directly on the radiographic film with the assistance of a millimeter ruler, properly positioned on the illuminator. The following measurements were taken: superior bi-iliac diameter (SBID); inferior bi-iliac diameter (IBID); biiliac average diameter (BIAD); right diagonal diameter (RDD); left diagonal diameter (LDD); sacro-pubic diameter (SPD), and the entrance area of the pelvis (EAP). The superior bi-iliac diameter was measured by drawing a cross straight to the longitudinal diameter of the pelvis in the smaller diameter of the sacroiliac joint. The inferior bi-iliac diameter was taken by drawing a straight line parallel to the SBID diameter which is measured at the site of the ilium-pubic junction (Fig.1). To measure the diagonal diameters, we stablished the starting and ending point of the diagonal diameter as the upper and lower biiliac diameters extremities lines (as shown in Figure 1, the diameter called RDD began in the upper left point and ended the right point of IBID). The third cross-sectional diameter, the bi-iliac average, which extends from the medial surface of the right ilium to the medium surface of the left ilium was traced at the point of intersection of the diagonal and parallel diameters to the superior and inferior bi-iliac diameters. Thus, the sacro-pubic 


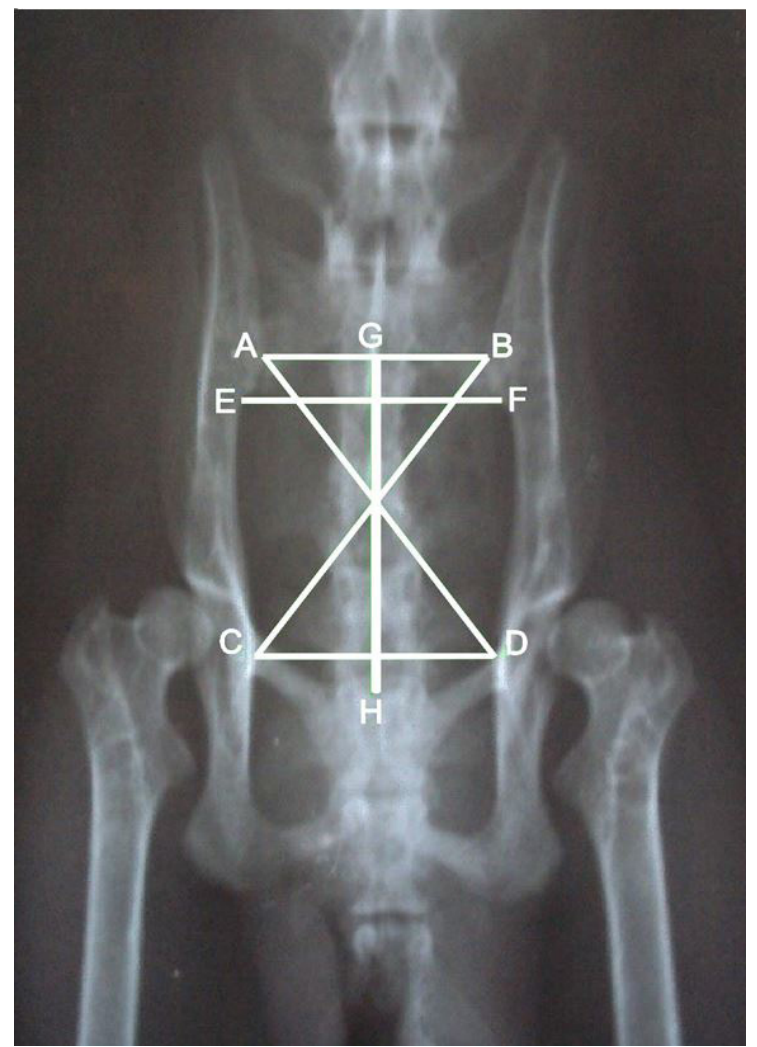

Fig.1. Digitalized radiographic image of the Saimiri sciureus female, ventrodorsal position: $\mathrm{SBID}=$ superior bi-iliac diameter $(\mathrm{AB})$, $\mathrm{BIAD}=$ bi-iliac average diameter (EF), IBID = inferior bi-iliac diameter (CD), RDD = right diagonal diameter (AD), LDD = left diagonal diameter $(\mathrm{BC}), \mathrm{SPD}=$ sacro-pubic diameter $(\mathrm{GH})$. diameter was measured from the central point of superior bi-iliac diameter to the cranial part of the pubic symphysis.

Considering that the pelvis comprises a regular elliptical set of bones, the area of the pelvic inlet (AEP) was calculated using the following formula ESL = (bi-iliac average diameter $/ 2) \mathrm{x}$ (sacro-pubic diameter/2) x $\pi$ (Ramadinha 2003, Valle 2004).

Statistics. Descriptive analyzes were performed (mean, median and standard deviation); analysis of variance; Pearson correlation analysis to verify possible correlations between the studied parameters; and Student's t-test, to check the difference between the values obtained for adult and subadult females.

\section{RESULTS}

The results obtained from the superior bi-iliac diameter (SBID); inferior bi-iliac diameter (IBID); bi-iliac average diameter (BIAD); right diagonal diameter (RDD); left diagonal diameter (LDD); sacro-pubic diameter (SPD); and the entrance area of the pelvis (EAP) measurements from ventrodorsal radiography projections of 11 pelvises of Saimiri sciureus females, are shown in Table 1 and 2 . There was statistical significance between the values for adult females and subadults to SBID, BIAD, RDD, LDD, SPD and EAP. Correlation was calculated between body weight and the variables measured in the pelvis (Table 3 ).

The Pearson correlation coefficients were high, significant and positive for: BIAD and SBID (0.7745), RDD and LDD (0.9855), RDD and SPD (0.9519), RDD and EAP (0.9280), RDD and WEIGHT (0.7741), LDD and SPD (0.9609), LDD and EAP (0.9585), LDD and WEIGHT (0.8004), SPD and EAP (0.9834), and SPD and WEIGHT (0.8258), EAP and WEIGHT (0.8512) (Table 4).

Table 1. Pelvic diameters $(\mathrm{cm})$ measured directly on radiographic film and entrance area of the pelvis

$\left[E A P=\left(b i-i l i a c\right.\right.$ average diameter/2) $X($ sacro-pubic diameter/2) $\mathrm{X} \pi] \mathbf{c m}^{2}$ from adult Saimiri sciureus females

\begin{tabular}{|c|c|c|c|c|c|c|c|c|}
\hline Animals & SBID & BIAD & IBID & RDD & LDD & SPD & EAP & WEIGHT (kg) \\
\hline 1 & 1.800 & 2.000 & 1.700 & 2.900 & 2.900 & 2.900 & 4.553 & 0.765 \\
\hline 2 & 1.800 & 2.000 & 1.550 & 2.600 & 2.600 & 2.200 & 3.454 & 0.570 \\
\hline 3 & 1.600 & 2.000 & 1.800 & 2.700 & 2.700 & 2.400 & 3.768 & 0.600 \\
\hline 4 & 1.800 & 2.000 & 1.800 & 2.800 & 2.800 & 2.600 & 4.082 & 0.605 \\
\hline 5 & 1.600 & 1.900 & 1.650 & 2.800 & 2.800 & 2.500 & 3.728 & 0.590 \\
\hline 6 & 1.700 & 1.900 & 1.600 & 2.700 & 2.700 & 2.600 & 3.877 & 0.610 \\
\hline 7 & 1.700 & 1.900 & 1.700 & 2.900 & 2.850 & 2.600 & 3.877 & 0.630 \\
\hline Averages & 1.714 & 1.957 & 1.686 & 2.771 & 2.764 & 2.543 & 3.906 & 0.624 \\
\hline Medians & 1.700 & 2.000 & 1.700 & 2.800 & 2.800 & 2.600 & 3.877 & 0.605 \\
\hline $\mathrm{SD}$ & 0.083 & 0.049 & 0.087 & 0.103 & 0.095 & 0.199 & 0.318 & 0.060 \\
\hline
\end{tabular}

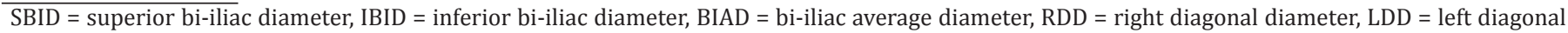
diameter, $\mathrm{SPD}=$ sacro-pubic diameter, $\mathrm{EAP}=$ entrance area of the pelvis, $\mathrm{S}=$ significant, NS = non-significant.

Table 2. Pelvic diameters $(\mathrm{cm})$ measured directly on radiographic film and entrance area of the pelvis

[EAP = (bi-iliac average diameter/2) X (sacro-pubic diameter/2) X $\pi] \mathbf{c m}^{2}$ from subadult Saimiri sciureus females

\begin{tabular}{|c|c|c|c|c|c|c|c|c|}
\hline Animals & SBID & BIAD & IBID & RDD & LDD & SPD & EAP & WEIGHT(Kg) \\
\hline 1 & 1.550 & 1.800 & 1.500 & 2.300 & 2.300 & 1.700 & 2.402 & 0.500 \\
\hline 2 & 1.600 & 1.900 & 1.500 & 2.600 & 2.600 & 2.150 & 3.206 & 0.530 \\
\hline 3 & 1.500 & 1.800 & 1.700 & 2.700 & 2.600 & 2.300 & 3.249 & 0.565 \\
\hline 4 & 1.700 & 1.900 & 1.800 & 2.400 & 2.400 & 1.650 & 2.460 & 0.550 \\
\hline Averages & 1.588 & 1.850 & 1.625 & 2.500 & 2.475 & 1.950 & 2.829 & 0.536 \\
\hline Medians & 1.570 & 1.850 & 1.600 & 2.500 & 2.500 & 1.920 & 2.833 & 0.540 \\
\hline SD & 0.074 & 0.050 & 0.130 & 0.158 & 0.130 & 0.281 & 0.399 & 0.024 \\
\hline
\end{tabular}

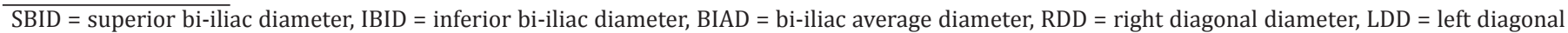
diameter, SPD = sacro-pubic diameter, EAP = entrance area of the pelvis, $\mathrm{S}=$ significant, NS = non-significant. 
Table 3. Averages (X), variances (V) of pelvimetry data obtained from adults (A) $n=7$ and subadults (SA), $\mathrm{n}=4$ of Saimiri sciureus, $\mathrm{T}$ test represented the different parameters

\begin{tabular}{|c|c|c|c|c|}
\hline Parameter & $\mathrm{X}$ & $\mathrm{V}$ & Test $\mathrm{t}$ & Result \\
\hline SBID A & 1.71 & 0.01 & $\mathrm{P}<0.05$ & $S$ \\
\hline SBID SA & 1.59 & 0.01 & & \\
\hline BIAD A & 1.96 & 0.00 & $\mathrm{P}<0.05$ & S \\
\hline BIAD SA & 1.85 & 0.00 & & \\
\hline IBID A & 1.68 & 0.01 & $P>0.05$ & NS \\
\hline IBID SA & 1.62 & 0.02 & & \\
\hline RDD A & 2.77 & 0.01 & $\mathrm{P}<0.05$ & S \\
\hline RDD SA & 2.5 & 0.03 & & \\
\hline LDD A & 2.76 & 0.01 & $\mathrm{P}<0.05$ & S \\
\hline LDD SA & 2.5 & 0.03 & & \\
\hline SPD A & 2.54 & 0.05 & $\mathrm{P}<0.05$ & S \\
\hline SPD SA & 1.95 & 0.11 & & \\
\hline EAP A & 3.91 & 0.11 & $\mathrm{P}<0.05$ & S \\
\hline EAP SA & 2.8 & 0.21 & & \\
\hline
\end{tabular}

SBID = superior bi-iliac diameter, IBID = inferior bi-iliac diameter, $\mathrm{BIAD}=$ bi-iliac average diameter, $\mathrm{RDD}=$ right diagonal diameter, $\mathrm{LDD}=$ left diagonal diameter, $\mathrm{SPD}=$ sacro-pubic diameter, $\mathrm{EAP}=$ entrance area of the pelvis, $\mathrm{S}=$ significant, $\mathrm{NS}=$ non-significant.

Table 4. Values referring to the correlation coefficient (r) between variables in adult females and subadults of Saimiri scireus

\begin{tabular}{ccccccccc}
\hline & SBID & BIAD & IBID & RDD & LDD & SPD & EAP & WEIGHT (Kg) \\
\hline SBID & 1.0000 & 0.7745 & 0.2263 & 0.3510 & 0.4377 & 0.4044 & 0.5186 & 0.5695 \\
BIAD & 0.7745 & 1.0000 & 0.3764 & 0.4583 & 0.5614 & 0.4993 & 0.6461 \\
IBID & 0.2263 & 0.3764 & 1.0000 & 0.3640 & 0.3476 & 0.2518 & 0.2978 \\
RDD & 0.3510 & 0.4583 & 0.3640 & 1.0000 & 0.9855 & 0.9519 & 0.9280 & 0.5630 \\
LDD & 0.4377 & 0.5614 & 0.3476 & 0.9855 & 1.0000 & 0.9609 & 0.9585 & 0.7741 \\
SPD & 0.4044 & 0.4993 & 0.2518 & 0.9519 & 0.9609 & 1.0000 & 0.9834 \\
EAP & 0.5186 & 0.6461 & 0.2978 & 0.9280 & 0.9585 & 0.9834 & 1.0000 & 0.8258 \\
WEIGHT & 0.5695 & 0.5630 & 0.3875 & 0.7741 & 0.8004 & 0.8258 & 0.8512
\end{tabular}

SBID = superior bi-iliac diameter, IBID = inferior bi-iliac diameter, BIAD = bi-iliac average diameter, RDD = right diagonal diameter, LDD = left diagonal diameter, $\mathrm{SPD}=$ sacro-pubic diameter, $\mathrm{EAP}=$ entrance area of the pelvis.

\section{DISCUSSION}

The passage of the fetus through the pelvis is a universal feature in almost all mammalian species during the birth process. However, the morphology of the pelvis varies according to locomotor habits, neonatal size and morphology of the species. The need for a rigid and a stable pelvis for locomotion limit the offspring's size so that it can successfully pass through it at birth. Species with a small body and with a developed brain, such as primates, may have greater difficulty in delivery due to cephalopelvic disproportion (Leutenegger 1990, Trevathan 2015). One of the species in which reproductive difficulties facing the limit of this feature can be suspected is the Saimiri sciureus, a species that presents highly frequent reports of dystocia in animal houses (Abee 1989). This study reports pelvimetry data from radiographic images. It was observed that the DBIM average value was lower than the DSP one, which categorizes the pelvis of the Saimiri scireus as dolicopelvic, similar to what is observed for ruminants and pigs (Toniollo \& Vicente 2003 - ruminant and pig, Araujo et al. 2014 - pig). The pelvis of dolicopelvic animals is characterized by presenting the cranial portion in an oval shape and in a flattened shape laterally. The ischium is roughly excavated and arched ventrally at its caudal extremity (Toniollo \& Vicente 2003). There are other studies performed with primates, such as with the Aotus azarai infulatus (Valle 2004) and with the Leontopithecus sp. (Ramadinha 2003) which also presented dolicopelvic pelvises. When considering other domestic animals such as dogs, pelvic morphology varies by race (Pafaro 2007). A previous study involving adult females of Saimiri correlated pelvimetry measurements with data on the birth of healthy progeny, still births or abortions. There was a significant statistical difference in the variables studied between females who delivered healthy progeny and the ones who delivered stillborn ones (Aksel \& Abee 1983). In the reported study there was a difference in the measurement of the "exit" of the pelvis, which is the distance between the lateral margins of the obturator foramen in the sciatic branch measured on ventrodorsal radiographs (Aksel \& Abee 1983). The authors found no difference between females of the two groups and between the measurements of top and bottom bi-iliac diameter.

By comparing the data obtained in this study with those of Aksel \& Abee (1983) for females who conceived healthy progeny, it is observed that the mean SBID and IBID values from that study are higher than the data obtained in this work in Brazil. In the study of Aksel \& Abee (1983), which was conducted in the United States, females showed SBID $1.84+0.09 \mathrm{~cm}$ and IBID $1.98+0.13 \mathrm{~cm}$, while in the present study the found values were $1.714+0.083 \mathrm{~cm}$ and $1.686+0.087 \mathrm{~cm}$ for adults and $1.588+0.074$ and $1.625+0.130$ to subadult females. Even when comparing the values obtained from females with stillborn progeny $(1.87+0.08$ and $1.92+0.10)$ we noted that the Aksel \& Abee (1983) values were superior. 
At the institution where the study was conducted, cases of dystocia are not frequently reported, so it can be assumed that the discrepancy between the results were found due to different lineages in different research laboratories.

In the present study it was observed that sub-adult females have lower SBID and lower pelvis area when compared to the adult females, suggesting higher risk of obstructed labor, being even more evident if we compare the values obtained by Aksel \& Abee (1983), which suggest that reproduction is not recommended at this stage.

By analyzing the correlation of variables we observed high positive correlation between EAP, SPD, LDD and RDD and weight. Considering then that a lower pelvis area (EAP) has a high correlation with lower weight amongst the females analyzed, this study suggests the usage of the weight of females as an initial parameter selection for playback. However, it would be useful to conduct a preliminary radiographic image for confirmatory correlation with previous data, since in the present study there were females of different groups of similar weight.

Data obtained in a study with Aotus azarai infulatus (owl monkey) (Valle 2004), showed that only two measures were lower in Aotus sp females when compared to the ones found in this study, which are the SBID and IBID; the value of RDD was similar and the LDD values, BIAD, SPD, EAP were higher, which is consistent with the Owl Monkey' larger size and weight. In pelvimetry study in females of owl monkeys, the mean weight was of $0.96+0.1$, while the average weight of females of Saimiri scireus was 0.624 for adult females and 0.540 for subadult females. The lower values of SBID and IBID demonstrate that despite their larger sizes, owl monkey females have narrower pelvises than the Squirrel Monkey ones. For the other three species of primates in which the indirect pelvimetry technique was used, we observed a SBID of 1.27, 1.37 and 1.32, IBID 1.37, 1.34 and 1.38, BIAD of 1.72, 1.80 and 1.77 and EAP of 2.74, 2.87 and 2.90 for Leonthophitecus chrysopygus, L. chrysomelas, and L. rosalia respectively, which are lower values than the ones found in the present study. However, the values are justified due to the smaller size of the lion tamarins (Monteiro 2012).

Pelvimetry is a relatively simple examination and of low risk. Its use in predicting dystocia in animals is reported in the literature, mainly with farm animals (Valle 2004). In these species, direct pelvimetry is often performed due to the difficulty of performing radiography due to the size of the animal (Oliveira \& Gheller 2009). In small animals there are few studies endorsing the technique. Pafaro (2007) conducted a study with females of different breeds of dogs in an attempt to establish reference values for racial pelvimetry. For cats, the 2012 study shows that there is sexual dimorphism of the pelvis and differences in brachycephalic and mesaticephalic animals. However, the authors concluded that the indirect pelvimetry is not a technique of a good predictive value in determining internal pelvic measurements (Monteiro 2012).

The use of indirect pelvimetry in veterinary medicine of wild animals is still sparse, possibly due to the employment of anesthesia for correctly-positioned radiographs (Cloete \& Haughey 1990, Van Donkersgoed et al. 1993), which increases risk in the performance of the technique.

For humans, many studies report that pelvimetry accomplished through radiographs have limited value in predicting dystocia
(Irurhe et al. 2012), and suggest that this is an unnecessary method to predict cephalopelvic disproportion. In medicine pelvimetry is no longer used because of the possibility of magnetic resonance (Stark et al. 1985). Measurements of the pelvis via radiographs resulted in errors of up to $10 \%$, while its realization by magnetic resonance imaging is more accurate, showing a maximum error of 1\% (Stark et al. 1985, Lenhard et al. 2010).

For wildlife animals there are few pelvimetry radiographic data. Values were found for the owl Monkey (Valle 2004), the Lion Tamarin (Ramadinha 2003) and the Agouti (Santos \& Ferraz 2013) and data in magnetic resonance imaging were missing. More precise imaging diagnosis examinations are not part of routine in vivarium animal studies. This study aimed at describing the Squirrel Monkey pelvimetry performed on radiographs in ventrodorsal projections to serve as a basis for future studies, using pelvic measurements and dystocia prediction of neotropical primates, and to elucidate whether this simple and inexpensive technique could assist in reproductive difficulty of squirrel monkeys raised in laboratories. Moreover, primate colonies were stablished mostly by wild caught animals (Lavergne et al. 2003), resulting in a lack of standardization of the animals amongst colonies. Therefore, it is important to state the differences amidst animals from different vivaria, which justifies the comparison between Aksel \& Abee (1983) study and the present one.

\section{REFERENCES}

Abee C.R. 1989. The squirrel monkey in biomedical research. ILAR News 31(1):11-20. http://dx.doi.org/10.1093/ilar.31.1.11.

Aksel S. \& Abee C.R. 1983. A pelvimetry method for predicting perinatal mortality in pregnant quirrel monkeys (Saimiri sciureus). Lab. Anim. Sci. 33(2):165-167. PMid:6855185.

Andrade A., Andrade M.C.R., Marinho A.M. \& Ferreira Filho J. 2010. Biologia Manejo e Medicina de Primatas Não-Humanos na Pesquisa Biomédica. Scielo, Rio de Janeiro. 471p.

Andrade M.C.R., Ribeiro C.T., Silva V.F., Molinaro E.M., Gonçalves M.A.B. Marques M.A.P., Cabello P.H. \& Leite J.P.G. 2004. Biologic data of Macaca mulatta, Macaca fascicularis, and Saimiri sciureus used for research at the Fiocruz Primate Center. Mem. Inst. Oswaldo Cruz 99(6):581-589. http:// dx.doi.org/10.1590/S0074-02762004000600009. PMid:15558168.

Araujo A.A.O., Farias L.A., Biagiotti D. \& Ferreira G.J.B.C. 2014. Pelvimetria de suinos das linhagens Agroceres e DanBred. Revta Bras. Ciênc. Vet. 21(4):262-267.

Boubli J.-P., Rylands A.B., De la Torre S. \& Stevenson P. 2008. Saimiri sciureus The IUCN Red List of Threatened Species, Cambridge.

Brady A.G. 2000. Research techniques for the Squirrel Monkey (Saimiri sp.). LAR J. 41(1):10-18. PMid:11406698.

Campos A.I.M. 2010. Estabelecimento do padrão biométrico corpóreo e pélvico e da relação entre as medidas corpóreas externas e as medidas pelvimétricas de cadelas da raça Buldogue Francês. Dissertação de Mestrado em Medicina Veterinária, Universidade Estadual do Ceará, Fortaleza. 70p.

Cloete S.W.P. \& Haughey K.G. 1990. Radiography pelvimetry for the estimation of pelvic dimentions in Merino, Dormer and S.A. Mutton Merino ewes. J. S. Afr. Vet. Assoc. 61(2):55-58. PMid:2286985.

Eneroth A., Linde-Forsberg C., Uhlhorn M. \& Hall M. 1999. Radiographic pelvimetry for assessment of dystocia in biches: a clinical study in two terrier breeds. J. Small Anim. Pract. 40(6):257-264. http://dx.doi. org/10.1111/j.1748-5827.1999.tb03076.x. PMid:10404485.

Irurhe N.K., Duru F.L., Ibeabuchi N.M., Adewunmi M.A., Okanlawon O.A. \& Adekola 0.0. 2012. X-ray pelvimetry and labour outcome in term 
pregnancy in a rural Nigerian population. Nig. Q. J. Hosp. Med. 22(2):113116. PMid:23175909.

Lavergne A., Catzeflis F., Lacôte S., Barnaud A., Bordier M., Mercereau-Puijalon 0. \& Contamin H. 2003. Genetic analysis of the Saimiri breeding colony of the Pasteur Institute (French Guiana): development of a molecular typing method using a combination of nuclear and mitochondrial DNA markers. J. Med. Primat. 32(6):330-340. http://dx.doi.org/10.1046/j.16000684.2003.00038.x. PMid:14641788.

Lenhard M.S., Johnson T.R., Weckbach S., Nikolaou K., Friese K. \& Hasbargen U. 2010. Pelvimetry revisited: analyzing cephalopelvic disproportion. Eur. J. Radiol. 74(3):e107-e111. http://dx.doi.org/10.1016/j.ejrad.2009.04.042. PMid:19443160.

Leutenegger W. 1990. Encephalization and obstetrics in primates with particular reference to human evolution. p.85-95. In: Armstrong E. \& Falk D. (Eds), Primate Brain Evolution: methods and concepts. Plenum, New York.

Monteiro C.L.B. 2012. Pelvimetria e ultrassonografia para avaliação obstétrica em gatas. Tese de Doutorado em Medicina Veterinária, Universidade Estadual do Ceará, Fortaleza. 101p.

Nogalski Z. \& Mordas W. 2012. Pelvic parameters in holstein friesian and jersey heifers in relation to their calving. Pakistan Vet. J. 32(4):507-510.

Oliveira L.F. \& Gheller V.A. 2009. Evaluation of internal pelvic measurements of Holstein cattle from Minas Gerais in Brazil. Ciênc. Anim. Bras. 8(Suppl.1):802-807.

Pafaro V.2007. Pelvimetria radiográfica em diferentes raças de fêmeas caninas adultas (Canis familiaris Linnaeus, 1758). Dissertação de Mestrado em Medicina Veterinária, Universidade Estadual de São Paulo, Jaboticabal. 38p.

Ramadinha L.S. 2003. Pelvimetria em micos-leões. Tese de Doutorado em Anatomia de Animais Domésticos, Faculdade de Medicina Veterinária e Zootecnia, Universidade de São Paulo, São Paulo. 59p.
Ramin A.G., Daniel R.C.W., Fenwick D.C. \& Verrall R.G. 1995. Pelvic parameters, growth rate, puberty, and their interrelationships in young dairy heifers. Reprod. Domest. Anim. 30(3):117-123. http://dx.doi. org/10.1111/j.1439-0531.1995.tb00616.x.

Santos E.M. \& Ferraz M.S. 2013. Pelvimetria radiográfica em cutias (Dasyprocta prymnolopha Wagler, 1831) criadas em cativeiro. Iniciação científica, Universidade Federal do Piauí, Teresina. 2p.

Stark D.D., McCarthy S.M., Filly R.A., Parer J.T., Hricak H. \& Callen P.W. 1985. Pelvimetry by magnetic resonance imaging. Am. J. Roentgenol. 144(5):947950. http://dx.doi.org/10.2214/ajr.144.5.947. PMid:3872578.

Tardif S., Bales K., Williams L., Moeller E.L., Abbott D., Schultz-Darken N., Mendoza S., Mason W., Bourgeois S. \& Ruiz J. 2006. Preparing new world monkeys for laboratory research. LAR J. 47(4):307-315. PMid:16963811.

Toniollo G.H. \& Vicente W.R.R. 2003. Manual de Obstetrícia Veterinária. Varela, São Paulo. 124p.

Trevathan W. 2015. Primate pelvic anatomy and implications for birth. Philos. Trans. R. Soc. Lond. B, Biol. Sci. 370(1663):20140065. http://dx.doi. org/10.1098/rstb.2014.0065.

Valle C.M.R. 2004. Pelvimetria em macacos-da-noite (Aotus azara linfulatus Kuhl,1820). Dissertação de Mestrado em Anatomia de Animais Domésticos e Silvestres, Faculdade de Medicina Veterinária e Zootecnia, Universidade de São Paulo, São Paulo. 101p.

Van Donkersgoed J., Ribble C.S., Booker C.W., McCartney D. \& Janzen E.D. 1993. The predictive value of pelvimetry in beef cattle. Can. J. Vet. Res. 57(3):170-175. PMid:8358677.

Wells J.C.K., Silva J.M. \& Stock J.T. 2012. The obstetric dilema: an ancient game of russian roulete, or a variable dilema sensitive to ecology? Yearb. Phys. Anthropol.149(Suppl.55):40-71. http://dx.doi.org/10.1002/ajpa.22160. 